\title{
ASSESSMENT OF CARBONATED AND HEALTHY DRINKS CONSUMPTION PATTERN AMONG UNDERGRADUATES IN OBAFEMI AWOLOWO UNIVERSITY, ILE- IFE, OSUN STATE
}

\author{
IDUMAH, F.O., ORUMWENSE, L.A., AWE, F., IREM, J.N., ABDULLAHI, O.A., \\ OGUNLANA, S.O. AND OLUMAKINWA, O.E. \\ Forest Economics and Extension Services Department, Forestry Research Institute of \\ Nigeria, Jericho Hills Ibadan, Oyo State, Nigeria \\ *Corresponding author's e-mail: adetejuf@yahoo.com
}

\begin{abstract}
The study assessed carbonated and healthy drinks consumption pattern of the undergraduate students of Obafemi Awolowo University (OAU), IIe - Ife, Nigeria. Random sampling technique was employed in this study. The study relied on primary data which was collected through questionnaires. Data collected were analyzed using mean and percentages. The total number of respondents was 260 undergraduate students, which comprised 102 males and 158 females. Majority (47.3\%) of the respondents were between 17 - 20 years old and were single. It was indicated that majority (49.6\%) of the respondents has less than $\$ 10,000$ as income level from their monthly stipend. The result indicated that the carbonated drinks that the students consume the most were Fanta and Coke. Majority (38.5\%) of the respondents consume fruit smoothies while they sometimes (38.8\%) consume zobo drink. The result also reveals that zobo drink has the highest percentage (76.2\%) of consumption than other healthy drinks. The major factors influencing healthy drinks consumption based on individual perceptions were taste $(40.4 \%)$, price $(38.9 \%)$, preferences $(36.2 \%)$, and nutritional benefit $(35.0 \%)$ while price $(36.5 \%)$, taste $(35.8 \%)$, preferences $(33.5 \%)$ and availability on campus (31.5\%) were the major factors influencing carbonated drinks consumption based on individual perceptions. It is therefore recommended that the Federal and State Government should ensure proper health education of undergraduates regarding the nutritional benefits of healthy drinks as well as the adverse effects of carbonated drinks.
\end{abstract}

Keywords: carbonated drinks, healthy drinks, consumption pattern, Obafemi Awolowo University (OAU)

https://doi.org/10.4314/jafs.v18i1.8

\section{INTRODUCTION}

Carbonated and healthy drinks constitute a great proportion of beverages consumed by the general populace in Nigeria especially among the youths. National Bureau of Statistics (NBS) indicates that $86.5 \%$ of Nigerian students consume carbonated drinks (NBS, 2010). German Engineering Federation ranked Nigeria as the fourth country with the most sales of soft drinks globally. The high rate in consumption carbonated drinks can also be attributed to the

Journal of the Faculty of Agriculture and Veterinary Medicine, Imo State University Owerri website: www ajol.info/index.php/jafs

Open Access article distributed under the terms of the Creative Commons License CC BY-NC 
Journal of Agriculture and Food Sciences Volume 18, Number 1, April, 2020 pp 82 - 92

Idumah, F.O., Orumwense, L.A., Awe, F., Irem, J.N3., Abdullahi, O.Ä., Ogunlana, S.O.\& Olumakinwa, O.E. growing population, urbanization, lack of portable water and climate change (hot weather) among others. The consumption of carbonated drinks among the youths can be attributed to change in lifestyle and dietary habits (Ngwu and Njoku, 2007). The food consumption patterns of Nigerians, for example, have equally shifted from more complex carbohydrate form of traditional diets to refined carbohydrate diets. The neglect of the traditional 'African' foods that provide high levels of dietary fibre in favour of the refined "Western foods" has been implicated in the rising incidence of chronic, diet-related non-communicable diseases such as obesity, diabetes, hypertension, coronary heart disease and stroke (Schmidhuler and Shetty, 2005).

Carbonated drinks are beverages that contain dissolved carbon dioxide. They are composed of high amount of sugar, calories, caffeine and provide no nutrition value. Damle et al., (2011) reported that the active ingredient in carbonated drinks are phosphoric acid (with an acidic $\mathrm{pH}$ generally less than three which is same as acetic acid), sugar, caffeine, colouring and flavouring agents. Among the carbonated drinks commonly consumed in Nigeria are Coca-cola (Coke), Fanta, Sprite, Pepsi, Seven up, malt drinks, and soda etc. Majority of those who consume carbonated drinks do so because of the taste, flavor without any consideration on the health implications of those drinks. Excessive consumption of these carbonated drinks, however, has negative effect on the body (Vartanian et al., 2007). The high sugar and acid contents of carbonated drinks have consequences for teeth. Studies have shown that regular intake of carbonated drinks can harm the teeth. This is because when carbonated drinks are taken, the sugar remains in the mouth, producing the processes that lead to tooth decay (Birkhead, 2007). The acid in these carbonated drinks further increase the likelihood of developing cavities, because the chemicals as well slowly erode the enamel of the teeth.

The World Health Organization (WHO) has reported that high consumption of free sugars results in a rise in body mass index (BMI). Therefore, WHO recommends that adults and children should reduce their daily intake of free sugars to less than $10 \%$ of their daily total energy intake (Pan and Hu, 2011). The high level of this carbonated consumption has some health consequences. Studies show that carbonated drinks intake has adverse effects on bone mineral density (BMD) (Tucker et al., 2006) and also an extrinsic factor of dental erosion (Lussi et al., 2004).

Notwithstanding the risks associated with excessive consumption of carbonated drinks, there are some benefits derivable from their consumption. Carbonated drinks can help in relieving stomach aches and even help people who are suffering from nausea or indigestion. Other benefits include improvement of swallowing ability, relieving constipation, decrease in risk of heart diseases and provision of energy (Mattes, 2006).

Healthy drinks (beverages), on the other hand, are drinks made from crops and fruits. They are classified as healthy drinks because they are devoid of artificial ingredients unlike the carbonated drinks. The common healthy drinks in Nigeria are soy milk made from soya beans, kunun zaki made either from millet (Pennisetum typoidum), sorghum (Sorghum bicolor), or maize (Zea mays); zobo made from dried Roselle plant flowers (Hibiscus

Journal of the Faculty of Agriculture and Veterinary Medicine, Imo State University Owerri website: www ajol.info/index.php/jafs

Open Access article distributed under the terms of the Creative Commons License CC BY-NC 
Journal of Agriculture and Food Sciences

Idumah, F.O., Orumwense, L.A., Awe, F., Irem, J.N., Volume 18, Number 1, April, 2020 pp 82 - 92

sabdariffa) and pito brewed with red or white sorghum malt and/or maize; it becomes alcoholic when it is allowed to ferment.

Healthy drinks provide a lot of benefits to the body. Some of the benefits associated with the consumption of health drinks include reduction in the risk of heart disease, lowering risk of diabetes, reduction in the risk of cancer, enhances calcium intake, brain enhancement and detoxification (Hasler, 2002).

There have been several studies on malnutrition and obesity among undergraduates in Nigeria (Akesode and Ajibode, 2000; Ben-Bassey et al., 2007; Akinpelu et al., 2008; Olumakaiye, 2008; Ojofeitimi et al., 2011; Maruf et al., 2013) but studies on the consumption of carbonated/soft drinks among youths in Nigeria are limited. Fadupin et al., (2014) in their study on the Knowledge, attitude and consumption pattern of alcoholic and sugar sweetened beverages among undergraduates in a Nigerian University found out that high consumption of alcoholic and sugar sweetened beverages (SSBs) remains a public health problem among the young adults. The study found a significant relationship between frequent consumption of sugar sweetened beverages by the respondents and being overweight and asserts that frequent consumption of sugar sweetened beverages could contribute to being overweight.

Meanwhile, Ansa et al., (2008) also did some work on soft drink consumption and overweight/obesity among Nigerian adolescents. The study aimed at assessing the magnitude of soft drink consumption in a cross section of adolescents in Nigeria and determining its association with obesity and overweight. The study revealed that there is no statistically significant association between the amount of soft drinks consumed and obesity/overweight.

Sholeye et al., (2018) also carried out a study on Snacking and sweetened beverage consumption among adolescents in Sagamu, Southwest Nigeria. The result indicated that the consumption of refined sugars was high among respondents, indicating presence of unhealthy dietary habits and recommended that concerted efforts at nutrition education through the school system should be made to reduce the risk of non-communicable diseases among adolescents.

This study therefore attempts to investigate the consumption pattern of carbonated and healthy drinks among undergraduate students of Obafemi Awolowo University, Ile - Ife, Nigeria.

It specifically assessed the;

1. socio-economic characteristics of the undergraduates in the study area,

2. frequency of carbonated and healthy drinks consumption among OAU undergraduates, availability and consumption of healthy drinks among OAU undergraduates and

3. factors influencing carbonated and healthy drinks consumption.

\section{MATERIALS AND METHODS}

The study was conducted at the Obafemi Awolowo University, Ile-Ife Osun State Nigeria. It currently has a student population of about 35,000 , comprising of both students with physical

Journal of the Faculty of Agriculture and Veterinary Medicine, Imo State University Owerri website: www ajol.info/index.php/jafs

Open Access article distributed under the terms of the Creative Commons License CC BY-NC 
Journal of Agriculture and Food Sciences Volume 18, Number 1, April, 2020 pp 82 - 92

disability and those without physical disabilities in undergraduate, post-graduate, full and part time study programs. The university has 13 faculties and 82 departments (Ijadunola, 2019).

Simple random sampling technique was employed in selecting undergraduates for the study. The random selection was executed using interval method of selecting a student at every 5th contact. The study focused only on undergraduate students because they are believed to exhibit demographics that are different from those of the postgraduate students. This is based on observation that postgraduate students are often working-class people, are married, and are more conscious of their feeding habits because of their age, exposure, and level of education (Bakare and Olumakaiye, 2016). Therefore, a total of 260 undergraduates from different departments were used for the study.

The study relied on primary data which was collected through a personally administered questionnaire. The respondents were interviewed and their responses were taken and recorded. Descriptive statistics were used to analyse data for the study.

\section{RESULTS AND DISCUSSION}

\section{Selected Personal Characteristics of Respondents}

The result in Table 1 revealed that majority $(60.8 \%)$ of the undergraduate students surveyed were female. Majority of the respondent were between 17-20 years old and were single. It was indicated that majority (49.6\%) of the respondents has less than $\$ 10,000$ as their income level from their monthly stipend while $32.3 \%, 10 \%, 3.8 \%, 3.1 \%$ and $1.2 \%$ of the respondents has between $\$ 10,000$ - $\$ 19,000, \$ 20,000-\$ 29,000, \$ 30,000-\$ 39,000$, more than $\$ 50,000$ and $\$ 40,000$ - $\$ 49,000$ respectively as income level from their monthly stipend. It was found that the students study disciplines include Art (16.9\%), Science (16.2\%), Agriculture (10.8\%), Administration (10.8\%), Education (10\%), Technology (10\%), Law (8.5\%), Social science (5\%), Basic medical (4.6\%), Pharmacy (1.9\%) etc. It was also observed that majority (78.1\%) of the respondents were Christians and were Yoruba's (85\%).

\section{Carbonated Drinks Consumption}

Table 2 depicts the results of the frequency of carbonated drinks consumption. It indicated that the majority $(38.1 \%, 31.5 \%, 34.6 \%, 39.2 \%, 31.9 \%$ and $36.5 \%)$ of the students consume coke, pepsi, seven up, fanta, sprite and malt respectively. The result indicated that the carbonated drinks that the students consume the most were coke and fanta.

\section{Healthy Drinks Consumption}

Table 3 also shows that majority (38.5\%) of respondents rarely consume fruit smoothies while they sometimes (38.8\%) consume zobo drink. Also, 61.2\%, 38.5\% and $38.2 \%$ never consume Pito, Kunun zaki and soy milk drinks respectively. This may be as a result of the unavailability of these drinks within the campus.

\section{Healthy Drinks availability and consumption}

Table 4 shows the frequency of healthy drinks availability and consumption among the students. It indicates that Fruits Smoothies are both available and also consumed (62.3\%) on the campus. Also, Zobo drink has the highest percentage $(76.2 \%)$ of consumption than other Journal of the Faculty of Agriculture and Veterinary Medicine, Imo State University Owerri website: www ajol.info/index.php/jafs

Open Access article distributed under the terms of the Creative Commons License CC BY-NC 
Journal of Agriculture and Food Sciences Idumah, F.O., Orumwense, L.A., Awe, F., Irem, J.N., Volume 18, Number 1, April, 2020 pp 82 - 92

healthy drinks. This may be because it is cheap. From the result, Soy milk were also available and were consumed by $45.4 \%$ of the surveyed students on campus while Pito drink was the least available and consumed.

\section{Factors Influencing Healthy Drinks Consumption}

The result from table 5 indicates that the main factors influencing Healthy Drinks consumption based on individual perceptions were taste $(40.4 \%)$, price $(38.9 \%)$, preferences $(36.2 \%)$, and nutritional benefit $(35.0 \%)$ while influence of friends $(14.6 \%)$ and advertisement (12.3\%) were not considered as the main factors influencing Healthy Drinks.

\section{Factors Influencing Carbonated Drinks Consumption}

Table 6, indicates that majority of the respondents believed that these few points which includes price $(36.5 \%)$, taste $(35.8 \%)$, preferences $(33.5 \%)$ and available on campus $(31.5 \%)$ were the major factors influencing carbonated drinks consumption based on individual perceptions while influence of friends (16.9\%) and season (16.2\%) were not considered as major factors influencing carbonated drinks consumption based on individual perceptions.

\section{CONCLUSION AND RECOMMENDATIONS}

The study revealed that all undergraduate students interviewed indulge in carbonated and healthy drink consumption to varying degrees. carbonated and healthy drinks consumption pattern is increasing among undergraduate students. From the consumption pattern it was observed that the majority of the students consume carbonated drinks over healthy drinks. These carbonated drinks have detrimental effects. Therefore, it is recommended that:

- the Federal and State Government should ensure proper health education of undergraduates regarding the nutritional benefits of healthy drinks as well as the adverse effects of carbonated drinks in order to equip them with necessary nutrition information and knowledge.

- there should be a general elective on physical health and nutrition education to engage every student in compulsory physical fitness exercise. 
Journal of Agriculture and Food Sciences

Volume 18, Number 1, April, 2020 pp 82 - 92

\section{REFERENCES}

Akesode, F.A. and Ajibode, H.A. (2000). Prevalence of obesity among Nigerian school children. Social Science \& Medicine. 17, 107-111.

Akinpelu, A.O., Oyewole, O.O. and Oritogun, K.S. (2008). Overweight and obesity: does it occur in Nigerian adolescents in an urban community? International Journal of Biomedical and Health Sciences. 4 (e-publication).

Ansa, V.O., Anah, M.U. and Ndifon, W.O. (2008). Soft drink consumption and overweight/obesity among Nigerian adolescents. CVD Prevention and Control. 3, 191-196.

Bakare, K.O. and Olumakaiye, M.F. (2016). Fast Food Consumption Pattern and Body Weight Status Among Students of Obafemi Awolowo University, Ile-Ife, Nigeria. African Journal of Food, Agriculture, Nutrition and Development (AJFAND). Vol. 12, No. 4, pp. 11185 - 11198. DOI: 10.18697/ajfand.76.15020

Ben-Bassey, U.P., Oduwole, A.O. and Ogundipe, O.O. (2007). Prevalence of Overweight and obesity in Eti-osa LGA, Lagos, Nigeria. Obesity Review. 8,475-479.

Birkhead, M. (2007). Multivariate Modelling. Cambridge University Press 103 - 112.

Damle, S.G., Bector, A. and Saini, S. (2011). The Effect of Consumption of Carbonated Beverages on the Oral Health of Children: A Study in Real Life Situation. Pesquisa Brasileiraem Odontopediatria eClínica Integrada, 11(1):35-40.

Fadupin, G.T., Ogunkunle, M.O. and Gabriel, O.O. (2014). Knowledge, attitude and consumption pattern of alcoholic and sugar sweetened beverages among undergraduates in a Nigerian University. African Journal Biomedical Research. 17: 75-82.

Hasler, C.M. (2002). Functional Foods: Benefits, Concerns and Challenges - A Position Paper from the American Council on Science and Health, The Journal of Nutrition, 132(12):3772-3781.

Ijadunola, M.Y., Ojo, T.O., Akintan, F.O., Adeyemo, A.O., Afolayan A.S. and Akanji, O.G. (2019). Engendering a conducive environment for university students with physical disabilities: assessing availability of assistive facilities in Nigeria, Disability and Rehabilitation. Assistive Technology, 14(4): 354-360.

Lussi, A., Jaeggi, T. and Zero, D. (2004). The role of diet in the aetiology of dental erosion. Caries Resources, 38: 34-44.

Maruf, F.A., Aronu, U.C., Chukwuegbu, K. and Aronu, A.E. (2013). Influence of gender on prevalence of overweight and obesity in Nigerian school children and adolescents. Tanzania Journal of Health Research. 15 (4).

Mattes, R. (2006). Fluid calories and Energy balance: the good the bad, and the uncertain. Physiology and Behavior, 89,66-70.

Journal of the Faculty of Agriculture and Veterinary Medicine, Imo State University Owerri website: www ajol.info/index.php/jafs

Open Access article distributed under the terms of the Creative Commons License CC BY-NC 
Journal of Agriculture and Food Sciences Volume 18, Number 1, April, 2020 pp 82 - 92

Idumah, F.O., Orumwense, L.A., Awe, F., Irem, P.R., Abdullahi, O.A., Ogunlana, S.O. \& Olumakinwa, O.E.

NBS (2010). Consumption Pattern in Nigeria, 2009/2010 Report of Harmonized Nigeria Living Standard Survey of the National Bureau of Statistics, Nigeria. Accessed on https://www.nigerianstat.gov.ng/nada/index.php/catalog/38.

Ngwu, E.K. and Njoku, A. (2007). Nutrition Knowledge, Quality of Diet and Factors Influencing Food Selection in a University Community. JHER, 8(1 \& 2): 224-232

Ojofeitimi, E.O., Olugbenga-bello, A., Adekanle, D.A. and Adeomi, A.A. (2011). Pattern and determinants of obesity among adolescent females in private and public schools in Olorunda local government area of Osun state, Nigeria: a comparative study. Journal of Public Health in Africa. 2(1):11.

Olumakaiye, M.F. (2008). Prevalence of underweight: a matter of concerns among adolescents in Osun State, Nigeria. Pakistan Journal of Nutrition. 7, 503-508.

Schmidhuber, J. and Shetty, P. (2005). Nutrition Transition, Obesity and Non-Communicable Diseases: Drivers, Out Look and Concerns. United Nations Standing Committee on Nutrition (SCN) No: 29: 13 - 19.

Sholeye, O.O., Animasahun, V., Salako, A.A. and Oduwole, A.D. (2018). Snacking and sweetened beverage consumption among adolescents in Sagamu, Southwest Nigeria. Nutrition \& Food Science, 48(3): 442-452.

Tucker, K.L., Morita, K., Qiao, N., Hannan, M.T., Cupples, L.A. and Kiel, D.P. (2006). Colas, but not other carbonated beverages, are associated with low bone mineral density in older women: The Framingham Osteoporosis Study. The American Journal of Clinical Nutrition, 84(4):936-942, https://doi.org/10.1093/ajcn/84.4.936

Pan, A. and Hu, F.B. (2011). Effects of carbohydrates on satiety: differences between liquid and solid food. Current Opinion in Clinical Nutrition and Metabolic Care, 14(4):38590 .

Vartanian, L.R., Schwartz, M.B. and Brownell, K.D. (2007). Effects of soft drink consumption on nutrition and health: a systematic review and metaanalysis. American journal of public health,97(4), 667-675. https://doi.org/10.2105/AJPH.2005.083782 
Journal of Agriculture and Food Sciences

Idumah, F.O., Orumwense, L.A., Awe, F., Irem, J.N 89 Volume 18, Number 1, April, 2020 pp 82 - 92

Abdullahi,.A., Ogunlana, S.O. And Olumakinwa, O.E.

\section{APPENDIX}

Table 1: Socio-economic characteristics of respondents

\begin{tabular}{|c|c|c|}
\hline Characteristics & Frequency & Percent \\
\hline \multicolumn{3}{|l|}{ Gender } \\
\hline Female & 158 & 60.8 \\
\hline Male & 102 & 39.2 \\
\hline \multicolumn{3}{|l|}{ Age Category (years) } \\
\hline$\leq 6$ & 7 & 2.7 \\
\hline $17-20$ & 123 & 47.3 \\
\hline $21-24$ & 96 & 37 \\
\hline $25-28$ & 31 & 12 \\
\hline$>29$ & 3 & 1.2 \\
\hline \multicolumn{3}{|l|}{ Marital Status } \\
\hline Married & 14 & 5.4 \\
\hline Single & 243 & 93.5 \\
\hline Divorced & 3 & 1.2 \\
\hline \multicolumn{3}{|l|}{ Religion } \\
\hline Christian & 203 & 78.1 \\
\hline Islam & 53 & 20.4 \\
\hline Traditional & 2 & 0.8 \\
\hline Other & 2 & 0.8 \\
\hline \multicolumn{3}{|l|}{ Ethnic Group } \\
\hline Yoruba & 221 & 85.0 \\
\hline Igbo & 25 & 9.6 \\
\hline Hausa & 3 & 1.2 \\
\hline Others & 7 & 2.7 \\
\hline \multicolumn{3}{|l|}{ Faculty of Study } \\
\hline Science & 42 & 16.2 \\
\hline Agriculture & 28 & 10.8 \\
\hline Art & 44 & 16.9 \\
\hline Law & 22 & 8.5 \\
\hline Basic medical & 12 & 4.6 \\
\hline Administration & 28 & 10.8 \\
\hline Education & 26 & 10.0 \\
\hline Technology & 26 & 10.0 \\
\hline Social science & 13 & 5.0 \\
\hline Nursing science & 1 & .4 \\
\hline Pharmacy & 5 & 1.9 \\
\hline Biochemistry & 1 & .4 \\
\hline Botany & 2 & .8 \\
\hline Accounting & 1 & .4 \\
\hline Zoology & 1 & .4 \\
\hline Clinical science & 1 & .4 \\
\hline Environmental design & 2 & .8 \\
\hline International relation & 1 & .4 \\
\hline Linguistics and African Language & 1 & .4 \\
\hline English & 1 & .4 \\
\hline
\end{tabular}

Journal of the Faculty of Agriculture and Veterinary Medicine, Imo State University Owerri website: www ajol.info/index.php/jafs

Open Access article distributed under the terms of the Creative Commons License CC BY-NC 
Idumah, F.O., Orumwense, L.A., Awe, F., Irem, J.शి., Journal of Agriculture and Food Sciences Abdullahi, O.A., Ogunlana, S.O. And Olumakinwa, O.E. Volume 18, Number 1, April, 2020 pp 82 - 92

History

2

.8

Total Income/month (

$<10,000$
$10,000-19,000$
$20,000-29,000$
$30,000-39,000$
$40,000-49,000$
$>50,000$

$129 \quad 49.6$

$84 \quad 32.3$

$26-10.0$

$10 \quad 3.8$

321.2

$>50,000$

Source: Field Survey, 2019

Table 2: Frequency of Carbonated Drinks Consumption

\begin{tabular}{lllllllllllll}
\hline S/N & Type & \multicolumn{2}{c}{ Never } & \multicolumn{2}{c}{ Rarely } & \multicolumn{2}{c}{ Sometimes } & \multicolumn{2}{c}{ Often } & \multicolumn{2}{c}{ Always } \\
\hline & & Freq & \% & Freq & \% & Freq & \% & Freq & \% & Fre & \% \\
q & \\
\hline 1 & Coke & 15 & 5.8 & 73 & 28.1 & 99 & 38.1 & 47 & 18.1 & 26 & 10 \\
2 & Pepsi & 24 & 9.2 & 118 & 45.4 & 82 & 31.5 & 25 & 9.6 & 11 & 4.2 \\
3 & Seven up & 27 & 10.4 & 107 & 41.2 & 90 & 34.6 & 27 & 10.4 & 9 & 3.5 \\
4 & Fanta & 9 & 3.5 & 79 & 30.4 & 102 & 39.2 & 53 & 20.4 & 17 & 6.5 \\
5 & Sprite & 27 & 10.4 & 110 & 42.3 & 83 & 31.9 & 28 & 10.8 & 12 & 4.6 \\
6 & Malt & 21 & 8.1 & 89 & 34.2 & 95 & 36.5 & 37 & 14.2 & 18 & 6.9
\end{tabular}

Source: Field Survey, 2019

Table 3: Frequency of Healthy Drinks Consumption

\begin{tabular}{llllllllllll}
\hline S/N & Type & \multicolumn{2}{c}{ Never } & \multicolumn{2}{c}{ Rarely } & \multicolumn{2}{c}{ Sometimes } & \multicolumn{2}{c}{ Often } & \multicolumn{2}{c}{ Always } \\
& & Freq & \% & Freq & \% & Freq & \% & Freq & \% & Freq & \% \\
\hline 1 & Fruit & 56 & 21.5 & 100 & 38.5 & 69 & 28.5 & 21 & 8.1 & 14 & 5.4 \\
& smoothies & & & & & & & & & & \\
2 & Zobo & 21 & 8.1 & 82 & 31.5 & 101 & 38.8 & 37 & 14.2 & 19 & 7.3 \\
3 & Pito & 159 & 61.2 & 66 & 25.4 & 24 & 9.2 & 10 & 3.8 & 1 & .4 \\
4 & Kununzaki & 100 & 38.5 & 89 & 34.2 & 50 & 19.2 & 12 & 4.6 & 9 & 3.5 \\
5 & Soy milk & 94 & 38.2 & 97 & 37.3 & 54 & 20.0 & 15 & 5.8 & 2 & .8 \\
\hline
\end{tabular}

Source: Field Survey, 2019

Journal of the Faculty of Agriculture and Veterinary Medicine, Imo State University Owerri website: www ajol.info/index.php/jafs

Open Access article distributed under the terms of the Creative Commons License CC BY-NC 
Journal of Agriculture and Food Sciences Idumah, F.O., Orumwense, L.A., Awe, F., Irem, J.N., bdullahi, O.A., Ogunlana, S.O. And Olumakinwa, O.E.

Table 4: Healthy Drinks availability and consumption

\begin{tabular}{llllllllll}
\hline S/N & Types & \multicolumn{2}{c}{$\begin{array}{c}\text { Available on } \\
\text { campus }\end{array}$} & \multicolumn{2}{c}{$\begin{array}{c}\text { Consumed on } \\
\text { campus }\end{array}$} & \multicolumn{2}{c}{ Both } & \multicolumn{2}{c}{ None } \\
& & Freq & \% & Freq & \% & Freq & \% & Freq & \% \\
\hline 1 & Fruits & 47 & 18.1 & 16 & 6.2 & 162 & 62.3 & 35 & 13.5 \\
& smoothies & & & & & & & & \\
2 & Zobo & 41 & 15.8 & 11 & 4.2 & 198 & 76.2 & 10 & 3.8 \\
3 & Pito & 24 & 9.2 & 25 & 9.6 & 48 & 18.5 & 163 & 62.7 \\
4 & Soy milk & 41 & 15.8 & 30 & 11.5 & 118 & 45.4 & 71 & 27.3 \\
5 & Kunun zaki & 42 & 16.2 & 30 & 11.5 & 112 & 43.1 & 76 & 29.2 \\
\hline
\end{tabular}

Source: Field Survey, 2019

Table 5: Factors Influencing Healthy Drinks Consumption

\begin{tabular}{|c|c|c|c|c|c|c|c|c|c|}
\hline \multirow[t]{2}{*}{$\mathrm{S} / \mathrm{N}$} & \multirow[t]{2}{*}{ Factors } & \multicolumn{2}{|c|}{ Strongly Agree } & \multicolumn{2}{|c|}{ Agree } & \multicolumn{2}{|c|}{ Disagree } & \multicolumn{2}{|c|}{ Strongly Disagree } \\
\hline & & Freq & $\%$ & Freq & $\%$ & Freq & $\%$ & Freq & $\%$ \\
\hline 1 & Price & 96 & 38.9 & 88 & 33.8 & 56 & 21.5 & 20 & 7.7 \\
\hline 2 & $\begin{array}{l}\text { Available on } \\
\text { campus }\end{array}$ & 78 & 30.0 & 136 & 52.3 & 38 & 14.6 & 8 & 3.1 \\
\hline 3 & $\begin{array}{l}\text { Available at } \\
\text { home }\end{array}$ & 68 & 26.2 & 121 & 46.5 & 61 & 23.5 & 10 & 3.8 \\
\hline 4 & Taste & 105 & 40.4 & 108 & 41.5 & 36 & 13.8 & 11 & 4.2 \\
\hline 5 & Preferences & 94 & 36.2 & 118 & 45.4 & 41 & 15.8 & 7 & 2.7 \\
\hline 6 & $\begin{array}{l}\text { Health } \\
\text { condition }\end{array}$ & 78 & 30.0 & 108 & 41.5 & 56 & 21.5 & 18 & 6.9 \\
\hline 7 & $\begin{array}{l}\text { Influence of } \\
\text { friends }\end{array}$ & 26 & 10.0 & 63 & 24.2 & 133 & 51.2 & 38 & 14.6 \\
\hline 8 & Season & 31 & 11.9 & 105 & 40.4 & 97 & 37.3 & 26 & 10.0 \\
\hline 9 & Smell & 54 & 20.8 & 104 & 40.0 & 84 & 32.3 & 18 & 6.9 \\
\hline 10 & $\begin{array}{l}\text { Nutritional } \\
\text { benefit }\end{array}$ & 91 & 35.0 & 114 & 43.8 & 48 & 18.5 & 7 & 2.7 \\
\hline 11 & $\begin{array}{l}\text { Production } \\
\text { and handling }\end{array}$ & 73 & 28.1 & 113 & 43.5 & 84 & 24.6 & 10 & 3.8 \\
\hline 12 & Advertisement & 44 & 16.9 & 84 & 32.3 & 100 & 38.5 & 32 & 12.3 \\
\hline
\end{tabular}

Source: Field Survey, 2019

Journal of the Faculty of Agriculture and Veterinary Medicine, Imo State University Owerri website: www ajol.info/index.php/jafs

Open Access article distributed under the terms of the Creative Commons License CC BY-NC 
Idumah, F.O., Orumwense, L.A., Awe, F., Irem, J.2ి?., Journal of Agriculture and Food Sciences Abdullahi, O.A., Ogunlana, S.O. And Olumakinwa, O.E. Volume 18, Number 1, April, 2020 pp 82 - 92

Table 6: Factors Influencing Carbonated Drinks Consumption

\begin{tabular}{|c|c|c|c|c|c|c|c|c|c|}
\hline \multirow[t]{2}{*}{$\mathrm{S} / \mathrm{N}$} & \multirow[t]{2}{*}{ Factors } & \multicolumn{2}{|l|}{$\begin{array}{l}\text { Strongly } \\
\text { Agree }\end{array}$} & \multicolumn{2}{|l|}{ Agree } & \multicolumn{2}{|c|}{ Disagree } & \multicolumn{2}{|c|}{$\begin{array}{l}\text { Strongly } \\
\text { Disagree }\end{array}$} \\
\hline & & Freq & $\%$ & Freq & $\%$ & Freq & $\%$ & Freq & $\%$ \\
\hline 1 & Price & 96 & 36.5 & 95 & 36.5 & 51 & 19.6 & 18 & 6.9 \\
\hline 2 & Available on campus & 82 & 31.5 & 100 & 38.5 & 56 & 21.5 & 22 & 8.5 \\
\hline 3 & Available at home & 71 & 27.3 & 108 & 41.5 & 62 & 23.8 & 19 & 7.3 \\
\hline 4 & Taste & 93 & 35.8 & 107 & 41.2 & 44 & 16.9 & 16 & 6.2 \\
\hline 5 & Preferences & 87 & 33.5 & 107 & 41.2 & 52 & 20.0 & 14 & 5.4 \\
\hline 6 & Health condition & 70 & 26.9 & 88 & 33.8 & 80 & 30.8 & 22 & 8.5 \\
\hline 7 & Influence of Friends & 38 & 14.6 & 75 & 28.8 & 103 & 39.6 & 44 & 16.9 \\
\hline 8 & Season & 37 & 14.2 & 93 & 35.8 & 88 & 33.8 & 42 & 16.2 \\
\hline 9 & Smell & 43 & 16.5 & 94 & 36.2 & 86 & 33.1 & 37 & 14.2 \\
\hline 10 & Nutritional benefit & 66 & 25.4 & 93 & 35.8 & 74 & 28.5 & 27 & 10.4 \\
\hline 11 & $\begin{array}{l}\text { Production and } \\
\text { handling }\end{array}$ & 58 & 22.3 & 103 & 39.6 & 77 & 29.6 & 22 & 8.5 \\
\hline 12 & Advertisement & 48 & 18.5 & 85 & 32.7 & 88 & 33.8 & 39 & 15.0 \\
\hline
\end{tabular}

Source: Field Survey, 2019

Journal of the Faculty of Agriculture and Veterinary Medicine, Imo State University Owerri website: www ajol.info/index.php/jafs

Open Access article distributed under the terms of the Creative Commons License CC BY-NC 